\title{
полІтичний дискУРс
}

DOI 10.31558/2617-0248.2020.5.2

УДК 323.2/304;398

\section{ПОЛІТИЧНИЙ ФОЛЬКЛОР ЯК ПРОТЕСТНИЙ ДИСКУРС С.ЕФРЕМОВА (ЗА МАТЕРІАЛАМИ ЩОДЕННИКІВ 1923 - 1929 рр.)}

ORCID ID: https://orcid.org/0000-0002-2988-620X

\section{Мацишина I. В., д. політ.н., професор Донецького національного університету імені Василя Стуса}

Політичний фольклор, як рефлексія на політичні процеси, має прагматичний аспект у вигляді політичних анекдотів. Формування сюжетів, навколо яких створюється вербальна історія, вказує на ступінь суспільної уваги до політичних явищ, фактів та політичних акторів. Тому для дослідника таких текстів важливі не тільки самі анекдоти, а й теми, навколо яких вибудовувався сюжет. Як інструмент історичної пам'яті, що може використовуватися у політичних цілях, політичний анекдот здатен емоційно доповнювати або заперечувати історичну пам'ять. Звідси акцент на одних історичних подіях, та відсутність сюжетів по іншим подіям свідчить про трансляцію смислу, що має переривчасту частоту кодів. Які розпізнаються завдяки спільному культурному простору, але у публічному просторі знаходяться під контролем влади, що має як інструменти блокування, так і власний механізм розповсюдження. Звідси дослідник має справу як з контрольованими, так і з протестними політичними анекдотами.

Використання емоційних образів «наших» та «інших» через політичні анекдоти поляризує суспільство, що може призводити як до розколу, так і до об'єднання нації. Тому важливим $€$ дослідження саме рефлексії змін та очікувань, які відображаються через дискурс повсякденності на прикладі політичних анекдотів.

Проводиться аналіз політичних анекдотів, що записані у «Щоденниках» українського громадського діяча Сергія Єфремова з 1923 по 1929 рр. Наголошується на протестному дискурсі політичних анекдотів, які як віддзеркалювали протестне ставлення до політичного режиму, так і створювали вже нові неофіційні політичні дискурси. Через дослідження певних форм, прийомів, метафор досліджено сміхову комунікацію і доведена подвійна структура «теорії звільнення» на особистісному та політичному рівнях.

Ключові слова: анекдоти, дискурс, Єфремов, протест, щоденники.

Matsyshyna I. V. Political folklore as a protest discourse of S.Yefremov (by the Diaries. 1923 - 1929) Political folklore, as a reflection on political processes, has a pragmatic aspect in the form of political anecdotes. The formation of plots around which a verbal story is created indicates the degree of public attention to political phenomena, facts and political actors. Therefore, for the researcher of such texts, not only the anecdotes themselves are important, but also the topics around which the plot was built. As a tool of historical memory that can be used for political purposes, a political anecdote can emotionally complement or deny historical memory. Hence the emphasis on some historical events, and the lack of plots on other events indicates the translation of meaning, which has an intermittent frequency of codes. Recognized by a common cultural space, but in a public space, they are under the control of a government that has both blocking tools and its own dissemination mechanism. Hence, the researcher deals with both controlled and protesting political anecdotes.

The use of emotional images of "ours" and "others" through political anecdotes polarizes society, which can lead to both division and national unification. Therefore, it is important to study the reflection of changes and expectations, which are reflected through the discourse of everyday life on the example of political anecdotes.

The analysis of political anecdotes recorded in the "Diaries" of Ukrainian public person Serhiy Yefremov from 1923 to 1929 is conducted. The protest discourse of political anecdotes is emphasized, which both reflected the protest attitude to the political regime and created new unofficial political discourses. Through the study of certain forms, techniques, metaphors, laughter communication is studied and the dual structure of the "theory of liberation" at the personal and political levels is proved.

Keywords: anecdotes, discourse, Yefremov, protest, diaries. 
«Анекдотичні часи й анекдотичні люде!» С.Сфремов

Сергій Єфремов та його щоденники, що були написані у 1923 - 1929 рр. розкривають ретроспективу історичних подій в Україні того часу через суб'єктну присутність автора. Будучи сином священика, Сергій Олександрович Єфремов вступив до Київської духовної семінарії, після закінчення якої став дяком Йорданської церкви. Пізніше закінчив юридичний факультет Київського університету Святого Володимира, після чого почав займатися дослідженням літератури. Головними темами для нього були національні питання, не насильницький соціалізм. Був одним з засновників Української демократичної партії, а після іiі розколу очолив її лівий напрям разом з Ф.Матушевським та Б.Грінченком, який назвали УРП (Українська радикальна партія). Пізніше ці дві партії об’єдналися в УДРП. Друкувався в газеті «Громадська думка», часописі «Рада», «Боротьба». Не зважаючи на те, що співпрацював у Центральній Раді, критично ставився до ії діяльності. Після революції 1905 р. разом з групою однодумців заснував ТУП (Товариство український поступовців). Був заступником М.Грушевського та очолював секретаріат з національних питань у Центральній Раді. Разом з В.Винниченком їздив до Петербургу, де делегація висунула умови національно-територіальної автономії України перед Тимчасовим Урядом. До гетьманату П.Скоропадського ставився двояко: відкрито не сприймав, але розумів слабкість Центральної Ради. Схоже двояке ставлення було і до Директорії. У 1922 р. його було обрано віце-президентом Академії наук. У 1928 р. проти нього в пресі було розпочато кампанію на публічний осуд, а у 1929 р. заарештований по сфабрикованій справі під назвою «Спілка визволення України». Сергія Єфремова було позбавлено волі на 10 років, а у 1939 р. він помер в одному з таборів ГУЛАГу. Лише після 1989 р. його було реабілітовано.

Стан наукової розробки. У своїх «Щоденниках» С. Сфремов записував події в країні, власне ставлення до них та фіксував власне життя протягом семи років. Перечитуючи його записи можна відчути, як 3 кожним роком людина, яка ідею національного розвитку країни втілювала через власну громадську участь, поступово стає зайвою та критичною до диктатури монопартійності. «Гидотне фарисейство: 3 одного боку понавішувано скрізь портретів Шевченка, а з другого - нищать його твори способом далеко дурнішим, ніж царська цензура це робила», - пише він у 1924 році [4, с. 84].

Сьогодні «Щоденники, 1923 - 1929» знаходяться у центрі досліджень філологів, публіцистів, філософів, політологів. Наприклад, М. Наєнко досліджував народницьке письменство (романтичне та реалістичне) у стилі С.Сфремова та протиставлення його до модернізму в українській літературі. Л. Масенко цікавить лінгвістичний рівень автора, оскільки С.Сфремов займався проблемами орфографії, правопису та лексики української мови. «Мова “Щоденників” має стати і, безперечно, стане в майбутньому одним із важливих джерел для вивчення літературної мови відтворюваної доби. Відомо, скільки праці вклав Сфремов у справу формування української публіцистичної мови. Він був засновником і найактивнішим автором перших українських газет Наддніпрянщини - “Громадської думки”, “Ради”, “Нової Ради”» [6, с.20].

Наголошуючи на історичному періоді, в якому писалися «Щоденники», М. Виговський зазначає «суперечливий суспільно-політичний та соціально-психологічний механізм індивідуального перевтілення відомих вчених, письменників, лідерів українських опозиційних партій, їх ідейної адаптації до умов радянської влади», про що можна прочитати у «Щоденниках» [1, с.81]. Тому попереджає, що попри широкий фактаж історичних подій та політичних процесів, в першу чергу це суб'єктивне і місцями упереджене тлумачення подій. Дійсно, під час глибокого аналізу записів можна відчути критичне ставлення С.Єфремова до таких історичних постатей, як М.Грушевський, П.Дорошенко, М.Скрипник, М.Хвильовий, наукового колективу Академії наук. Його не задовольняє система освіти, яка була організована по всій вертикалі навчання, штучна українізація, низький професіоналізм номенклатури.

Т. Нагорна аналізує «Щоденники» як джерело суспільно-культурного та наукового життя в Україні у 1920-х рр. «С. Сфремов усвідомлював, що його записи стануть для нащадків цінним свідоцтвом очевидця становлення радянської тоталітарної системи. 3 цієї причини він їх і не знищив, хоча усвідомлював, яку загрозу вони становитимуть для його подальшої долі у разі арешту. Так і сталося, племінник Сфремова після його арешту виказав місце, де вони зберігалися. “Щоденники” С.О.Сфремова потрапили до рук органів ДПУ» [7, c.229-230].

Г.Калантаєвська та І.Сипченко у центрі дослідження виділяють публіцистичну діяльність вченого та специфіку більшовицьких періодичних видань. «У записах С. Сфремова повною мірою відображені названі якості радянських газет і видавництв. Органічним складником такої періодики були виконавці партійних завдань - редактори, видавці, цензори, коректори, рядові газетярі - інтерв'юери, фотокореспонденти, репортери тощо. У “Щоденниках” вони - “казенні пера”, “борзописці”, “монополісти друкованого слова”, а по-народному - “рябки”» [5, с.100].

Денисенко Г. та Денисенко О. акцентують увагу на історичній постаті самого Сергія Олександровича, який доклав багато зусиль до створення Національної бібліотеки України. Неприйняття більшовицької влади змусило його перебувати під постійним контролем партійних органів влади, пережити обшуки та бути кандидатом на вислання за кордон. Після усунення від роботи в Академії наук, у 1929 р. його було заарештовано за участь в організації «Союз визволення України».

Луїза Оляндер проводить філософський аналіз проблеми взаємодії «Я» та середовища у «Щоденниках» С.Єфремова з точки зору самопізнання та вольового протиставлення зовнішнім обставинам. Як вважає дослідниця, 
в умовах глобального тиску автор «Щоденників» був надзвичайно вимогливим до своєї освіти та власного світогляду. «Визначивши свою життєву мету, пильно придивляючись до самого себе, проявляючи аналітичність і конструктивну самокритичність, С. Єфремов спонукає до цього й інших іти шляхом знань» [9, с.77-78].

М. Чорнопиский досліджує політичний фольклор у текстах С.Сфремова та пояснює, що антисемітизм в анекдотах (якого доволі багато), виявився тому, що більшість євреїв опинились на боці радянської влади, яку автор «Щоденників» не сприймав. Н. Головецька провела класифікацію 146 анекдотів за ідейно-тематичним змістом та проаналізувала їх, виявивши специфіку поетики та їі актуальність у сьогоденні. Дослідниця виділяє чотири групи анекдотів: про історичні події 20-х pp, про історичних осіб (які були суб'єктами політичної діяльності), про цінності та життєві інтереси різних верств радянського суспільства, про українізацію 20-х років [2, с.23].

Для політологічних студій ці «Щоденники» цікаві не тільки фактами та особистими враженнями в умовах тоталітарного політичного режиму. Його записи можуть бути фактологічним документом феномену протестного дискурсу, що існував в часи радянської влади. Для нашого дослідження нотатки у «Щоденниках» дозволяють відкрити маловідомі фольклорні тексти, які можна сприймати як протестний дискурс проти радянської влади у Києві. Тому метою статті є дослідження протестного дискурсу через фольклор, який часто автор виділяв власною рубрикою у «Щоденниках» під назвою «3 новітнього фольклору». Предметом дослідження є політичний анекдот, який ми розуміємо як техніку розповіді - наратив. В центрі наративу знаходиться сюжет, а мета самої розповіді - репрезентація абсурдності радянської влади.

Методи дослідження: контент-аналіз та структурно-функціональний метод дозволи виділити основні метафори протиставлення автора «Щоденників» до політичних явищ та політичних акторів через фольклорний фактаж та карикатурне зображення радянської дійсності. Завдання: віднайти наративні форми розповіді політичних анекдотів; визначити основні теми, навколо яких вибудовувалися сюжетні форми; виділити протиставлення антигероїв до героїв.

Наративні форми. Безумовно, власне ставлення до політичного режиму та радянської влади вплинуло на тематичну добірку самих анекдотів автора. Рефлексія на каламбури, метафори, приказки, в яких осміювалася діюча радянська влада у місті Києві, представлена у «Щоенниках» сотнею політичних анекдотів. Їх можна розділити на дві групи за авторством:

анекдоти, щзо розповідали самі більшовики (С. Сфремов іноді так і пише «з комуністичних анекдотів»). Наприклад:

«3 комуністичних анекдотів. “На з’їді, коли Ленін робив доповідь про переможний хід революції, якийсь українець завважив: нічого з того не буде: жидів не вистарчить. "Не турбуйтесь, товаришу, на дурнів їх вистарчить” $[4$, с. 69].

анекдоти, щзо розповідали знайомі або випадкові незнайомі люди на вулицях міста («з українізаційних анекдотів»).

«3 новітнього фольклору. Молочниця селянка, що носила молоко до Києва, розказувала: “Перше був один цар, а тепер два настало: Ленін - наш ніби-то - та жидівський - Троцкін, чи якось там. Та їхній про них безпокоїться - от їм добре і живеться, а наш за нас не дбає - то нам і горе"» [4, с. 62].

За стилістикою наративну техніку розповіді анекдотів можна розподілити за наступними формами:

запитання - відповідь. Наприклад:

«“Хто ваш батько?” - “Священик”. - “Ага, значить, піп”. - “Нi, так «священик”. - “Хіба не все

одно? Яка ж різниця між попом і священиком?” - “А така, як між жидом і євреєм”» [4, с. 156].

розшифровки абревіатур.

«Комуністичний анекдот. Питання: “Что такое ВКП(б)”. Відповідь: “Воры, Конокрады,

Проститутки”. - “Но Проститутки - не русское слово”. - “Там в скобках стоит и по-русски - б...”” [4, с. 429].

діалог (як зазначає Н. Головецька, за жанровими ознаками це фацеції діалог у рамках непрямого мовлення, яким передано одноепізодний розвиток дії, що висвітлює певну політичну подію чи явище [2, с.25]. Наприклад:

«Стрівся на тім світі Микола II з Леніним. “А, що, Ілліч, горілку продаєте? - “Продаємо”. -

“А скільки градусів? - “38”. - “І варто ж було за 2 градуси таку веремію здіймати!”» [4, с. 49].

поєднання української та російської мов (як правило, російськомовні є або представниками влади, або їі прихильниками).

«Входить нібито пасажир до вагону - на всіх лавках лежать, хоч вагон і не спальний. До одного - дайте місце, сісти треба. “Я, - відповідає, - ответственный работник, ездил на агитацию, устал, нуждаюсь в отдыхе”. До другого - те ж саме: “ответственный”... До третього - i той “ответственный”. Нарешті бачить - лежить простий єврейчик з пейсами. "Посуньтесь, щоб можна мені сісти” - “Ну, и я тоже ответственный!...” - “Як то?” - “А так: я ответственный еврей - я за них показуючи на комуністів - бужу отвечать, корда они п’ятами накивают. Так мне тоже надо выспаться хоть тепер спокойно"» [4, с. 64].

Основні теми сюжетів анекдотів. Серед сотні політичних анекдотів тематична складова стосується у більшості трьох загальних блоків: анекдоти про політичних акторів (сьогодні це більше історичні постаті). 
«Ленін прислав з того світу Рикову телеграму: будь ласка, товаришу, подбайте, щоб Ленінград знов на Петроград чи Петербург повернули. А то я стрівся тут з Петром, він з своєю “дубинкою” - то, розумієш, що коштує мені ваша вигадка... Так змилуйтесь же, будь ласка!» [4, с. 92].

анекдоти про політичні подї та явщща, що відбувалися як всередині країни, так і за кордоном. Наприклад, С. Сфремов пише, що у 1924 р. червонець за три місяця піднявся у 15 разів. «В вересні коштував три мільярди на світську валюту, тепер вже до 50 міліярдів добігає» [4, с. 56].

«3 цього приводу анекдот: На “звіздинах” один робітник назвав сина Ільїчем (в честь Леніна), другий дочку - Розою (Люксембург). Підходить єврейчик. “Як хочеш назвати сина?” - “Червінчик”. “Чому Червінчик?” - “А нехай здоров росте так, як червінець”» [4, с. 56].

Зовнішня політика у більшості висвітлюється через особистісні стосунки представників Радянського Союзу з європейськими країнами.

«Заспорилися Мусоліні, Еріо, Макдональд і Чичерін, хто з них демократичніший. Вирішено зробити спробу. От Мусоліні й запер трьох конкурентів на демократизм вкупі з свинею в одне помешкання; хто довше висидить, той найдемократичніший. Минуло трохи часу- вискакує Макдональд, затуляючи носа: “не можу більше”. За ним незабаром Еріо. Минув ще якийсь часвискакує свиня: “і я не можу з ним видержати”. Чичерін виявив найбільше “демократизму”, що й свиня не видержала» [4, с. 140].

анекдоти про Украӥну, украӥнізачію та украӥнську мову.

«Комуністичний анекдот. Дійові особи - Петровський і Риков. Риков: «Ты хочеш, чтобы я тебе на украинизацию деньги давал. Да ведь и языка-то такого не существует». - Петровський: «Не, существует». - Риков: «какое там существует! Ну, например, как будет по-украинскиголова?»- П.: «Голова». - Р.: «Губы?» - П.: «Губи». - Р.: «Рука?». - П.: «Рука». - Р.: «Нога?». - П.: «нога». - Р.: «Жопа?». - П. (тріумфуючи): «срака!!!». - Р.: «И ты хочешь, чтобы я на эту самую сраку тебе полтора миллиона отпустил?!» [4, с. 386].

Іноді сам автор робить дописи до своїх анекдотів, які позначає певними характеристиками: «не анекдот, але на анекдот скидається», «не анекдот, але од усякого анекдота краще», «свіжий анекдот з “совєтських”», «з анекдотів про “чистку”», «анекдот про жида», «старі анекдоти» тощо.

Протиставлення «герой-антигерой». Як історія, сюжет якої грунтується на внутрішньому протиставленню між героями, анекдоти С.Сфремова насичені історичними постатями та подіями, які розкривають протестне ставлення автора Через тексти можна відчути відчай автора, який знаходився в умовах боротьби цензури та свободи слова, новим та старим режимами, протиставленням євреїв до українців, атеїзму до віри, більшовиків до інтелігенції, української мови до російської. Т.Нагорна пише, що «неодноразово порівнює С.Сфремов режим, що його встановили комуністи, із самодержавною Росією, і вбачає прямий спадкоємний зв'язок нової деспотії зі старою, з єдиною, правда, відмінністю - за масштабами пригнічення людини нова держава перевершила стару» [7, с.230].

3 одного боку, радянська влада представлена через постаті Леніна, Троцького, Рикова, Маркса, Чичерина, Зінов'єва. Кожен з них репрезентується через власні недоліки, що вбудовані в короткий анекдотичний текст. Формується уявлення про радянську владу, яка недолуга, непрофесійна, мстива та цінічна.

«3 Заповіту Троцького: мозок мій по смерті покласти в спирт, а тоді, дослідивши, спирт передати Рикову, а мозок - Сталіну [4, с. 737].

«Гра в карти. Хто в що любит грати: Риков - у п’яниці, Калінін - у дурня, Сталін - у короля» $[4$, c. 765$]$.

Більше анекдотів присвячені Л.Троцькому, біографія якого представлена у багатьох сюжетах. В них $\epsilon$ і натяк на вступну статтю Л.Троцького під назвою «Уроки жовтня» до власного третього тому, і про його життя у засланні у м. Вірний (стара назва м. Алма-Ата). У 1924 р. С.Сфремов записав анекдот, який з часом став дуже відомим за сюжетом і сьогодні використовується у фольклорних текстах, але вже $з$ іншими прізвищами:

«Сьогодні чув один анекдот, що ходив два роки тому. “Їде Троцький у купе для не куріїв. Навпроти сидить хтось і курить. Ще раз прохає- той не заважає. Тоді Троцький дає йому свою візитову картку. Той глянув, сховав у кишеню і курить. Троцький кличе кондуктора: “Забороніть цьому громадянинові курити". Курій мовчки виймає з кишені карту (Троцького) й дає кондукторові. Кондуктор глянув і конфіденційно до Троцького: "Раджу вам з цим не заходити - це Троцький, така, скажу вам, сволок, що нічого з ним не поробиш”» [4, с. 166].

3 іншого боку, радянська влада представлена в образах євреїв (у більшості- жидів), комсомольців, піонерів, комуністів. Їм протиставляються українці, селяни, містяни, які не $\epsilon$ героями сюжетів, а у більшості жертви радянського режиму.

«Виключний з партії жаліється: мене виключено тільки за те, що я схожий з вождями: походженням я - як Ленін (дворянин), відношенням до партії - Троцький (опозиціонер), з жіноцтвом поводжуся, як Луначарський (гомосексуально), а в приватному житті - як Риков (любить 3 скляним богом здоровкатись). От і догоди їм: одним честь, а других - виганяють [4, с. 582]. 
Висновки. Протестний дискурс у жанрі анекдотів на прикладі «Щоденників» Сергія Єфремова має релевантну форму. Вважаючи те, що серед теорій комізму є теорії зверхності, невідповідності, звільнення та ігрова теорія, теорія звільнення дозволяе розуміти короткі оповідальні сюжети з вигаданими історіями як форми протесту. Спираючись на роботу 3.Фройда «Дотеп та його стосунок до несвідомого», теорія звільнення має подвійну структуру і «анекдоти Єфремова» на це вказують. 3 одного боку, завдяки гумору знімається внутрішня напруга до зовнішніх політичних обставин, які учасники такої форми комунікації не в силах змінити. 3 іншого боку, сміх є реакцією на те, що заборонено. Відбувається вихід за межі контролю того, що заборонено владою. Сміються над тими, над ким заборонено сміятися. Використання стереотипів у жартах, створюваних та виконуваних тими, кого пригнічують чи хто незадоволений владою, здатне до швидкого розуміння і розповсюдження анекдотів серед учасників такої комунікації. Сміються ті, хто почувають себе пригніченими. Тому така сміхова культура не розважає, а більше є маркером внутрішнього драматизму.

«Один з членів ВУЦВК’а, селянин, приїхавши до Харкова на сесію, вирішив і свої господарські потреби задовольнити. “Чи не знаєте, де тут купити можна вожжей?” - питає. - “А як же, можна. Ходімте!”. Ведуть його до паперової крамниці, показують на стіну, де висять портрети: “Ви хотіли вождем - ось вони. Вибирайте, котрого хочете”. - “Та мені, чухає потилицю дядько, не тих, що вішають, а тих, що правлять" (віжки)» [4, с. 704].

Ще одне спостереження, що було зроблено під час аналізу політичних анекдотів стосується формування нового неофіційного дискурсу через анекдот. У 1925 р. С.Сфремов описує випадок, коли А. В. Луначарський, у ті часи нарком освіти, відвідував Першу зразкову трудову семирічну школу імені Т. Шевченка у Києві, яку очолював Володимир Федорович Дурдуківський. «Ходить по місту анекдот, - пише від 28 листопада 1925 р. С.Сфремов, - про одвідини Луначарським 1-ої трудової школи. Луначарський у своїй промові до школярів згадав, що він вчився тоді, коли українська мова була заборонена й буяла примусова русифікація, а тому то він і не вміє говорити по-українському» [4, с. 303]. На що голова школи Володимир Дурдуківський зауважив, що вчився теж в таких обставинах, але навчився говорити по українські і почуває себе українцем. «Хтось дотепно вигадав другу половину,- пише далі Єфремов, - й пустив між людей, і Володимира тепер часто запитують, чи то правда, що він так збрив Комісара народної освіти» [4, с. 303]. 3 цього допису можна побачити, що анекдот є не тільки наслідком протестного ставлення, але він здатен створювати вже нові неофіційні політичні дискурси.

Політичний анекдот, як дискурс спротиву до радянської влади тих часів, міг виконувати функції ідентифікації за політичними поглядами та ставленнями до режиму. I впливати на формування протестних груп. Тому за статею 54 Карного кодексу УРСР 1927 р. «За пропаганду або агітацію, яка полягає в заклику до повалення, підриву або послаблення радянської влади...» було покарання у вигляді позбавлення волі від шести місяців до 10 років виправних робіт, а у військовий час - розстріл. Покаранню підлягали не тільки ті, хто розповідав анекдоти, а й ті, хто на них реагував сміхом.

\section{Бібліографічний список:}

1. Виговський М. Ю. « Щоденники» академіка Сергія Єфремова: джерело вивчення номенклатури культурно-освітніх установ України 1920-х років. Пам'ять століть : Історичний науковий та літературний журнал. 2003. № 6. С. $81-91$.

2. Головецька Н. Український політичний анекдот на сторінках “Щоденників. 1923-1929” Сергія Єфремова. Народна творчість та етнографія. 2007. № 5. С. 23-27.

3. Денисенко Г., Денисенко О. Краєзнавчі нотатки Сергія Єфремова. Краєзнавство. 2000. № 1-2. С. $59-65$.

4. Сфремов С.О. Щоденники, 1923 - 1929. К. : ЗАТ «Газета «РАДА», 1997. 848 с.

5. Калантаєвська Г., Сипченко І. А пресі... пресі теж смоленським шляхом іти доведеться (радянська періодика і видавнича справа у Щоденниках Сергія Сфремова) . Образ. 2017. №. 3. С. 94-105.

6. Масенко Л. Цінне джерело: нотатки мовознавця про «Щоденники» Сергія Єфремова. Урок Украӥнської. 2000. №1. С.20-23.

7. Нагорна Т. Щоденники С. Єфремова як джерело для вивчення особливостей суспільно-культурного та наукового життя в підрадянській Україні 1920-х років. Вісник Київського національного лінгвістичного університету. Серія Історія, економіка, філософія. 2012. №. 17. С.228-234.

8. Наєнко М. Сергій Єфремов і ранні модерністи. Слово i Час. 2012. № 1. С. 117-120.

9. Оляндер Л. Я й середовище в Щоденнику (1.01. 1895 - 4.02. 1896) Сергія Єфремова: проблема самопізнання, формування особистості та вибір життєвої позиції. Султанівські читання. 2015. №. 4. С. 71-80.

10. Фройд 3. Дотеп та його стосунок до несвідомого. Пер. Я.М.Коган, М.В.Вульф. М. : АСТ, Мн. : Харвест, 2006. 480 с.

11. Чорнопиский М. Фольклорна політична сатира 20-х років ХХ століття у записах Сергія Єфремова : монографія. Львів : Видавничий центр ЛНУ ім. Івана Франка, 2001. 170 с.

\section{References:}

1. Vyhovskyi M. Yu. «Shchodennyky» akademika Serhiia Yefremova: dzherelo vyvchennia nomenklatury kulturno-osvitnikh ustanov Ukrainy 1920-kh rokiv. Pamiat stolit : Istorychnyi naukovyi ta literaturnyi zhurnal. 2003. №6. S. 81-91. 
2. Holovetska N. Ukrainskyi politychnyi anekdot na storinkakh "Shchodennykiv. 1923-1929" Serhiia Yefremova. Narodna tvorchist ta etnohrafiia. 2007. № 5. S. 23-27.

3. Denysenko H., Denysenko O. Kraieznavchi notatky Serhiia Yefremova. Kraieznavstvo. 2000. № 1-2. S. 59-65.

4. Iefremov S.O. Shchodennyky, 1923 - 1929. K. : ZAT «Hazeta «RADA», 1997. 848 s.

5. Kalantaievska H., Sypchenko I. A presi... presi tezh smolenskym shliakhom ity dovedetsia (radianska periodyka i vydavnycha sprava u Shchodennykakh Serhiia Yefremova). Obraz. 2017. №. 3. S. 94-105.

6. Masenko L. Tsinne dzherelo: notatky movoznavtsia pro «Shchodennyky» Serhiia Yefremova. Urok Ukrainskoi. 2000. №1. S.20-23.

7. Nahorna T. Shchodennyky S. Yefremova yak dzherelo dlia vyvchennia osoblyvostei suspilno-kulturnoho ta naukovoho zhyttia v pidradianskii Ukraini 1920-kh rokiv. Visnyk Kyivskoho natsionalnoho linhvistychnoho universytetu. Seriia Istoriia, ekonomika, filosofiia. 2012. №. 17. S.228-234.

8. Naienko M. Serhii Yefremov i ranni modernisty. Slovo i Chas. 2012. № 1. S. 117-120.

9. Oliander L. Ya y seredovyshche v Shchodennyku (1.01. 1895 - 4.02. 1896) Serhiia Yefremova: problema samopiznannia, formuvannia osobystosti ta vybir zhyttievoi pozytsii. Sultanivski chytannia. 2015. №. 4. S. 71-80.

10. Froid Z. Dotep ta yoho stosunok do nesvidomoho. Per. Ya.M.Kohan, M.V.Vulf. M. : AST, Mn. : Kharvest, 2006. $480 \mathrm{~s}$.

11. Chornopyskyi M. Folklorna politychna satyra 20-kh rokiv KhKh stolittia u zapysakh Serhiia Yefremova : monohrafiia. Lviv : Vydavnychyi tsentr LNU im. Ivana Franka, 2001. 170 s.

DOI 10.31558/2617-0248.2020.5.3

уДК 321.64:19.51

\section{ДИНАМІКА ЦИФРОВОГО ПОЛІТИЧНОГО ДИСКУРСУ РФ}

ORCID ID: https://orcid.org/0000-0001-9799-9786

Стеблина Н. О., к. н. соц. комунік., докторантка Донецького національного університету імені Василя Стуса

Під упливом цифровізації політичні актори отримують можливість звертатися до суспільства напряму, без посередництва 3МІ. У демократичних країнах офіційні дискурси трансформуються на рівні формату та структури, аби використати цю можливість. Тим не менш зміни офіційних дискурсів авторитарних режимів лишаються невивченими. У цьому дослідженні досліджується трансформація російського політичного дискурсу за чотирма показниками, при цьому розглядається співвідношення офіційного (сайт президента РФ) та неофіційного (інтернет-видання «Лента.ру») дискурсів упродовж 2005-2019 років. Проведений аналіз (із використанням комп'ютерних програм, написаних мовою Рython), дозволяє стверджувати, що за показниками емоційності, негативізму, інтертекстуальності (прямої та непрямої) російський офіційний дискурс $є$ мало активним. У ньому не відбувається зближення означених показників для офіційного та неофіційного дискурсів, як це стається у більш демократичних дискурсах. Таким чином, переорієнтація офіційного дискурсу на пряму комунікацію із суспільством та використання його для політичної боротьби для російського дискурсу не характерна. Слабка інтенсивність політичної взаємодії, що пояснюється особливостями російського політичного режиму, призводить до того, що показники емоційності та негативізму $\epsilon$ низькими для офіційного $(0,03 ; 0,03)$ та неофіційного $(0,2 ; 0,19)$ дискурсів. Також в російському офіційному дискурсі практично відсутня пряма інтертекстуальність - упродовж усього періоду спостережень $(0,003)$, непряма інтертекстуальність стає мало вираженою із 2010 року $(0,9)$. Показники для неофіційного дискурсу - вищі (0,04 - непряма; 0,15 - пряма), тим не менш порівняно із більш демократичними дискурсами вони $€$ недостатніми для того, щоб у політичній сфері відбувався повноцінний обмін ідей. Відтак, російські політичні актори практично не створюють привабливих для аудиторії меседжів, які б могли поширюватися як в офіційному, так і неофіційному дискурсах. Таким чином, для російського політичного дискурсу на даному етапі не $є$ характерною трансформація форматів та структури повідомлень, яка 6 уможливлювала характерну для цифрової доби пряму взаємодію між політичними акторами (представниками влади) та аудиторією.

Ключові слова: політичний дискурс, авторитарний режим, Росія, політичні емоції, негативізм, інтертекстуальність.

Steblyna N. O. Dynamics of Russian digital political discourse

In the digital world, political actors have been getting plenty of possibilities for a direct communication with society, without mass media participation. In democratic countries formats and structures of official discourses has been transforming in order to use the possibility. However, changes in authoritarian 